\title{
The Rise of Fraud Examination and Forensic Accounting in Africa: The Nigerian Experience
}

\author{
Wilson E. Herbert \\ Dept. of Banking \& Finance, Faculty of Management Sciences, Federal University, Otuoke, \\ Bayelsa State, Nigeria.
}

Ioraver N. Tsegba

Dept. of Accounting \& Finance, Federal University of Agriculture, Makurdi, Benue State, Nigeria

Emeka E. Ene

Dept. of Accounting \& Finance, Faculty of Management \& Social Sciences, Baze University, Abuja, Nigeria.

\section{Francis Onyilo}

Dept. of Accounting \& Finance, Faculty of Management \& Social Sciences, Baze University, Abuja, Nigeria.

\begin{abstract}
This paper documents the rise of fraud examination and forensic accounting education and research in Africa, using Nigeria to mirror the development. With attendant fraud and corrupt practices in Nigeria there are muted discussions on strategic ways to build capacity in the drive to curtail these unwholesome practices. The paper concludes, inter alia, that: (i) fraud examination and forensic accounting (FEFA) education has become an indispensable subject area in the light of the challenge of fraud and corruption in Nigeria's (and Africa's) economy; (ii) there is currently no formal structure for FEFA education in Nigerian tertiary education system even though there is some evidence of integration of forensic accounting education at the undergraduate and postgraduate levels; and (iii) due to the skill set required, FEFA education cannot be conveniently subsumed under traditional accounting programmes. The study recommends the articulation of a clear framework for FEFA education, coordinated by tertiary education regulators and inclusion of routine forensic audits as part of the corporate governance architecture of public and private sector organizations in Nigeria.
\end{abstract}

Keywords: Forensic accounting, fraud examination, corruption, financial crimes, National Universities Commission, Benchmark Minimum Academic Standards, Nigeria.

\section{INTRODUCTION}

Any attempt to develop conceptual foundations about the definition and identification of governance costs (transaction costs) in all organizational settings must first identify the drivers of governance costs and distinguish between the variations of strategic behaviour and incentives across different actors and governance costs within a geographic operational milieu (rules and actors). It is an accepted axiom that resources are finite in all governance or organizational settings. To be efficacious therefore, such resources must be allocated in a discriminating way. This implies that for the benefits to be realised, the opportunities of resources must be consciously tapped. In so doing, however, the costs of corruption, fraud and abuse, financial crimes and other associated egregious distortions are not conventionally factored into the configuration of scarce resources. Put differently, costs of governance administrative, production, cost of sales, marketing, finance, taxes, etc., - do not accept or incorporate corruption and associated vices as norms of transaction costs or hazards. Even in 
developing, especially Sub-Saharan African (SSA), countries where systemic corruption is endemic and concomitant with almost every government contract, official budgets do not inherently reflect the corruptly-inflated cost components. In fact, the more one hears of legislative budget scanning, the more the invention of new vocabularies, such as 'budget padding'. Yet, corruption, fraud and abuse - as the world was awoken by the scandalous fall of Enron, WorldCom, etc., and Bernard Madoff (through his pyramid scheme), Halliburton (through bribery, bid rigging, defrauding the military, and various other fraud schemes), Arthur Andersen (through opportunistic accounting practices), and several Nigerian banks constitute an egregious cost of doing business whose true nature is hidden, if reflected at all, in financial statements. As if that is all, most government appointments and privatizations of state-owned enterprises (SOEs) are mired and marred by corruption of the adverse selection genre.

The growing spate of corruption, fraud and financial crimes with devastating consequences on companies and national economies has compelled regulatory changes across national and regional boundaries. Hitherto, the general perception was that such vices were largely an internal event, primarily impacting the organization's net earnings or earnings per share (EPS). They were not conceived to have a major impact in the way businesses were conducted. However, that perception has considerably changed in recent times. Nowadays, the world understands better: organizations now know that the egregious effect of these offences goes beyond the bottom line. Basically, these vices serve to attenuate optimum pursuit of organizational goals; they limit organizational ability to economize on scarce resources, including information processing and decision-making capability, in transaction cost terms; they promote information hoarding, opportunism, bounded rationality and distortions. The associated negative publicity of corporate fraud breeds high reputational risks, stifles business prospects, and threatens business survival. These are the core transactional issues on which a comparative assessment of the rise of fraud examination and forensic accounting in Africa turns.

While fraud and financial crimes are perpetrated in every country, their density has been highest in SSA countries, with Nigeria as the most talked about for obvious reasons. First, apart from being the most populous nation in Africa, the impunity with which corruption is perpetrated in Nigeria has stood the country out as one of the most corrupt in the world. The nefarious activities of some Nigerians (notoriously known as 419 and highly placed public servants) have brought the country into international opprobrium. The situation is not helped by the almost daily reportage of one suspected fraudulent activity by one top government official or another, whether it is in contract award or arms procurement for the fight against the militant group Boko Haram. The fact is that in Nigeria, and in most SSA countries, fraud is being committed daily with brazen impudence, impunity and reckless abandon. Corruption which is a vicious and perverse form of fraud, has somehow eclipsed fraud due to its prevalence and the attendant effects on the populace and national development. Corruption is rife in state-owned enterprises (SOEs) and government agencies which have become a conduit by Government officials, legislators and politicians to divert funds through inflated contracts, bloated staff strength, and overpriced procurement of goods and services. The fraudulent monies would then be laundered into the financial system through concealed deposits in private pseudonym accounts, 'non-existent corporate' accounts, purchase of real estate, or donations to political parties, religious bodies and charities involved in the scheme.

Those entrusted with public funds for the provision of citizen welfare, security and public services and those assigned with the responsibility of ensuring public oversight, transparency 
and accountability in governance, have all allegedly been implicated in state-wide corruption, fraud and economic crimes. The pervasive corruption and money laundering inculpating most State governors, serving legislators and judges, top public servants, government contractors, and bank chief executives - currently being prosecuted by the Economic and Financial Crimes Commission (EFCC) and the Independent Corrupt Practices Commission (ICPC) - combine to provide anecdotal evidence of the spate of malfeasance in Nigeria. No arm of government - the executive, legislature or judiciary - is exculpated from corruption. This reinforces the characterization of 'palace fraud' where fraud perpetrators are either top government functionaries or corporate chief executives. Whereas technology is facilitating the evolution of 'new forms of fraud' in advanced economies, the trend in Nigeria and SSA is, however, being expedited by holding public office.

It is elementary that impunity influences the way Africa's corruption is both perpetrated and perceived, including the power to delude and misguide. Equally, it is generally conceded that it is not corruption per se that is dangerous or antithetical to development, rather the impunity with which it is perpetrated that makes it egregious. Impunity is the critical dimension for characterizing Africa's corruption, and indicates how and why it is a malediction to Africa's developmental strides. To be sure, impunity is commonplace in SSA countries that have weak institutions, especially weak legal systems. The ground that fosters corruption is equally one that promotes the phenomenon of strong individuals and weak institutions; it is also one that suffers from entrenched systems of political and economic patronage and prebendalism. Implicit in corrupt susceptibilities with impunity is the prevalent atmosphere of opportunism, or lack of candour or honesty in transactions. But for such general impunity and weak legal structures, corruption would attenuate in the presence of strict application of penalties for errant deviance. This organizational or structural failure to bring brazen perpetrators of corrupt deeds or public service violations to justice and redress adumbrates the 'economic development attention deficit disorder' or 'economic development inattentiveness' of most African governments.

Edward Coke's [1] presumption of actus non facit reum nisi mens sit rea (that is, "an act does not make a person guilty unless their mind is also guilty") is immediately invoked and resonates deeply in Nigeria's impunity towards fraud and corruption and their associated transactional frictions. In law, the general test of guilt is one that requires proof of fault, culpability or blameworthiness both in thought and action. Unfortunately, these do not yield easily to formal analysis, and have been relatively neglected or artificially discussed in formal economic settings. Both in theory and practice, the act of fraud, corruption and financial crime in general cannot be separated from the mind. The modern interpretation of the term, 'mens rea', describes the state of mind or inattention that, together with its accompanying conduct, constitutes an offence in criminal law. Prima facie, these activities, like murder, carry some element of premeditation. This distinction between the concept of culpability as a general requirement of guilt (the classic mens rea) and the impunity with which fraud, corruption and financial crimes are perpetrated underlies the foundations of their prosecution and potential deterrence in Nigeria and Africa at large.

The audacity of corruption in Nigeria, unlike advanced economies, is not just an act of the mind but a deliberate one perpetrated with total disregard for the law and its consequences. In fact, it is said that fraud and financial crimes agencies frown at those caught for 'small fraud', a euphemism for fraud offences considered inconsequential though running into tens of millions of naira. To drive the point home, the EFCC and ICPC do not entertain fraud complaints of N5 million or less. Going to the Nigerian Police with such complaints is a voyage into the abyss: a fruitless endeavour. The complainant may end up incurring huge personal costs for endless wasted effort. In addition, s/he may turn to be an accused and spend a lot of money to extricate 
from the clutches of corrupt enforcement agents. To be sure, the audacity and impunity of corruption in Nigeria not only challenges the orthodoxy of jurisprudence but also strikes at the root of its practice by disenabling the capacity of the law to facilitate voluntary exchanges to maximize the aggregate wealth of society, especially in weak legal systems. Thus, the mind absorbed in opportunistic proclivities is already trapped in self-interest seeking with guile by reason of lack of candour or honesty in transactions. As Williamson [2] and Herbert [3] observe, opportunistic inclinations pose both a threat and risk in the economy, especially in the absence of competitive (large numbers) exchange relations. Much of the fraud, abuse and impunity that militate against efficient economic management in the private and public sectors of SSA's economies cannot be (i) costlessly detected, or (ii) regarded or expressed as Alchian and Demsetz's [4] turpitudinal peccadilloes. In Nigeria, for example, practically every economic transaction is inflated by fraud aggregates, bounded rationality, uncertainty, and idiosyncratic behaviours which cumulatively (a) defy or compound efficiency analysis, and (b) impose market or organizational failure.

The challenges of weak economic growth, poor infrastructural syndrome and perennial poverty in Africa have their roots in weak leadership and corruption. There is overwhelming conclusion that the widespread corruption in Africa is the major impediment to both national and continental growth and development. Interestingly too, it is widely acknowledged that corruption in Africa is endogenous and affected by economic policies [5]. Thus, if the tree stump of unbridled systemic corruption is not removed, Africa cannot overcome its numerous socio-economic and political challenges.

Apart from the opportunistic proclivity of privileged top government officials, several factors conspire to both trigger fraudulent predisposition and militate against its fight in SSA. The growing army of unemployed youth, especially of the graduate genre, corrupt and inept governments and leadership at all levels, and infrastructure deficit in electricity, transportation and healthcare, are the perennial social incendiary devices that detonate insecurity, armed militia, disease, deprivation and destitution. The absence of social safety nets, such as unemployment benefits as obtained in advanced economies, exacerbates the state of depravity. Combating the sources as well as collateral implications of corruption, fraud and financial crimes in Nigeria and SSA is a daunting task. Combating corruption requires more sophisticated skills as fraudsters have advanced their cause through use of technology and multiple stratagems. To be sure, the trajectories of FEFA have changed abruptly not just in Africa but across the globe, cutting through time with a lot of momentum, in response to the changing landscape of national and global trends in corruption, fraud, and financial crimes.

\section{Landscape of FEFA in Nigeria}

As fraudsters have become more dangerously creative with devastating consequences, so has the configuration of fraud investigation become increasingly sophisticated with encouraging results. Forensic accounting, which has evolved to combat the growing rate and economic consequences of fraud and abuse, financial crimes and corruption, encapsulates specialized knowledge and specific skills to stumble up on the evidence of economic transactions [6]. Traditional accountants, however effective they may be, are not necessarily forensic accountants. The global economic consequences of recent accounting scandals juxtaposing the increasing spate of fraud and corruption have occasioned new national and international antifraud and anti-money laundering legislations. These have created a huge demand for fraud investigation and forensic accounting work. Increasingly, many professional accountancy firms are establishing specialized fraud examination and forensic accounting units to keep up with 
the workload. At the same time, organizations and government agencies are finding it difficult to recruit experienced and highly skilled forensic accountants and fraud examiners.

Being a forensic accountant or fraud examiner requires professional possession of multidisciplinary backgrounds and skills and knowledge to comprehend the trajectories of international crimes and fraud. In this respect, traditional accountants are both conceptually and professionally ill-equipped to deal with complex fraud, financial crimes, occupational abuse and corruption. This has induced the growing need for specialized skills in forensic accounting and fraud investigation in this 21st century of globalization, electronic commerce and the internet. In fact, the evolution of Certified Financial Forensics (CFF) certification program by the American Institute of Certified Public Accountants (AICPA) in June 2008 was a recognition of (a) the special skills and knowledge required of a forensic accountant, and (b) the high demand for forensic accountants which has propelled a large number of accountants to get involved without proper training in the ins and outs of the niche [7]. Many countries' professional accounting bodies have also joined the AICPA in establishing FEFA certification programmes. For example, in Nigeria, the Association of National Accountants of Nigeria (ANAN) and the Institute of Chartered Accountants of Nigeria (ICAN) - Nigeria's two statutory professional accountancy bodies - have recently established forensic accounting certification programmes for their members. In addition, ANAN established a special arm, known as the Society for Forensic Accounting \& Fraud Prevention (SFAFP), to power the specialized training and certification requirements of accountants, lawyers, and enforcement agents involved in fighting corruption and financial crimes. The SFAFP is equally available for those contemplating a career in fraud examination and forensic accounting (FEFA).

What these developments portray is that the landscape of FEFA has not only expanded in response to the bloom in accounting fraud and financial crimes, but also that the subject area is a rapidly growing discipline in at least three domains: (1) professional practice, (2) education and certification, and (3) research and publication [8]. The growing importance of FEFA practice motivates exploring their practical and scholarly nature. These domains both encapsulate and anchor the epistemological, methodological and ontological dimensions of FEFA. Like traditional accounting research, the purpose of FEFA education and certification, and research and publication is to encourage and facilitate the continuing debate on FEFA knowledge development. The academic conversation should be designed to explore the philosophy and complexity of investigating social phenomena, the shortcomings of extant research processes, and the importance of evaluating issues of practical relevance. Thus, as academic institutions contemplate the addition of FEFA into their curricula, it calls for an indepth examination of the way in which this process can be effectively conjugated. This is to ensure that the pedagogic content and delivery encompass idiosyncratic knowledge, skills and abilities necessary for individuals to function in the field as professionals.

In general, the power of FEFA, in relation to the other social sciences, is to be traced in no small part to the unremitting emphasis on net benefit analysis. The net benefit argument cannot be construed too narrowly in economic terms, as will be the case if the net benefits are calculated in or viewed from transaction-specific terms, without factoring the interaction effects. While a handful of African universities have added or are considering adding FEFA into their curriculum, the preceding situation has revealed a void in the significant skill set outcome that should be developed. But, this void needs theoretical validation, which is this study's raison d'être. As a country case in point, presently, there is no university or polytechnic in Nigeria offering forensic accounting either as an undergraduate or postgraduate programme. At best, what is obtainable is that a handful of Nigerian universities offer FEFA as a two or three credit unit taught course. This lacuna is traceable to the fact that the regulatory agencies - the National Universities Commission (NUC) for Universities, the National Board for Technical 
Education (NBTE) for Polytechnics and Colleges of Technology, and National Council for Colleges of Education (NCCE) for Colleges of Education - have not established Benchmark Minimum Academic Standards (BMAS) for the programme. The absence of BMAS for the programme is not the reason per se because it is not difficult to develop one, rather, there is a palpable regulatory reluctance towards the development of an undergraduate taught B.Sc. Forensic Accounting/B.Sc. Fraud Examination programme. The reason for this failure or negligence is also traceable to Nigeria's, and Africa's, bounded rationality in wide developmental, socio-economic and political respects.

Furthermore, it should be noted that the enabling law of the NUC, as with their counterparts in other African countries, empowers it to lay down minimum academic standards for all programmes taught in the Nigerian University System ${ }^{1}$. The BMAS is an amalgam of the Benchmark Style Statements and the revised Minimum Academic Standards. This merger, known as BMAS, "crisply enunciates the learning outcomes and competences expected of graduates of each academic programme without being overly prescriptive while at the same time, providing the requisite flexibility and innovativeness consistent with a milieu of increased institutional autonomy" [9]. The intervening implication of this is that no degree programme in any discipline can be undertaken by any Nigerian university without the BMAS. Unlike what obtains in advanced economies, the path to establishing a degree programme in a Nigerian university, regardless of its high demand, is difficult, tortuous and tedious, even with the BMAS. Sadly, Nigerian universities do not have the autonomous capacity to mount programmes of their choice or programmes that are not in the NUC's stable of approved programmes.

While many universities in different parts of the world have recognised the importance of systematic education and training of forensic accountants and fraud examiners, there is a noticeable lacuna in forensic accounting education and practice in Nigeria and other African countries. The leading reason for this void is that there are very few, just a handful of, Nigerian universities and polytechnics offering fraud examination and forensic accounting (FEFA) as a course unit in the accounting programme. Equally, the practice of FEFA is limited in every material respect in Nigeria, despite the plethora of fraud and abuse encompassing large-scale corruption, financial crimes and banks' financial scandals.

The case for a systematic education and training of forensic accountants and fraud examiners is firmly anchored in the changing nature and sophistication of financial transactions, the dynamics of Information and Communication Technology (ICT), and the imperatives of globalization. The joint effect of these is the rising incidence of financial statement fraud and other forms of occupational fraud and abuse as well as financial crimes across countries and economic sectors. First, since the early 1990s, several national and global surveys have shown the growing prevalence of fraud and abuse, bribery and corruption risks as a global phenomenon [10-17]. Second, because of the widely publicized fraudulent financial reporting scandals such as Enron, WorldCom, and others, there have been clarion calls by opinion leaders in the accounting profession for the provision of systematic education and training in fraud examination and forensic accounting [18]. Third, as the number of frauds and the amount of fraud losses increase both in human and financial terms, so have the opportunities for careers in forensic accounting and fraud management, as shown in Table 1. Fourth, as more accounting firms are opening forensic accounting departments vis-à-vis limited availability of

${ }^{1}$ Correspondingly, the enabling laws of NBTE and NCCE respectively empower them to lay down minimum academic standards for all programmes taught in polytechnics/colleges of technology and colleges of education. 
skilled recruits in this area, there is equally an increased pressure on organizations to strengthen their internal control systems as an integral part of their corporate governance framework. Building business confidence requires a strong corporate governance system to (a) reinforce the organization's control systems, (b) provide an early mechanism for conflict resolution, and (c) engender a renewed awareness of reputational risk.

Table 1: Fraud Examination/Forensic Accounting - Career Opportunities

\begin{tabular}{ll}
\hline Type of Employer & Type of Career \\
\hline Government \& Law & EFCC, ICPC, Police \& Military Intelligence Units, Inland Revenue Service, \\
Enforcement Agencies & Offices of Accountants-General and Auditors-General of Federal and State \\
& Governments, Federal and State Ministries of Finance, Other Governmental \\
& Agencies. \\
Public Accounting Firms & Forensic Accounting Units (FAU) of Public Accounting Firms. The FAU: \\
& Conducts forensic investigations; Provides litigation support services; \\
& performs financial statement fraud for clients; serve as expert witnesses in \\
& fraud cases they investigated; provides the following fraud-related services \\
& used to either perpetrate or conceal fraud: bankruptcy, divorce, tax fraud, and \\
& money laundering; provides internal audit and internal control consulting \\
& services. \\
& To institutionalize good corporate governance, modern organizations \\
& establish FAUs to strengthen their internal control/audit mechanisms, \\
Corporations & especially in large organizations. The goal of FAU is to prevent, detect, and \\
& investigate fraud within the organization. The staff/activity component \\
& includes internal auditors, corporate security officers, and in-house legal \\
& counsels. \\
& In addition to public accounting services, consulting firms with FAUs provide \\
& independent consultancy services in litigation fraud; Serve as expert \\
& witnesses in fraud cases under their investigation; Consult in fraud prevention \\
and detection, and Provide other fee-based work for their clients. & Lawyers are active agents in fraud cases. They provide litigation and defence \\
services for their clients (government agencies, companies and individuals) \\
who are facing fraud charges; big law firms also provide special investigation \\
services in fraud-suspected cases.
\end{tabular}

Source: Adapted with modifications from Zimbelman [19].

These are new frontiers in the skills kit of the fraud examiner and forensic accountant. Because the FEFA discipline is a relatively new one, it requires several years to build up the necessary skills and experience. The foregoing explains why forensic accounting is reportedly one of the hottest and most profitable career tracks for accounting majors and practicing accountants [20-23]. All of the foregoing points to one thing, which is: as the demand for skilled forensic accountants and fraud examiners (that is, forensic accounting education) is increasing, so is the supply (universities, polytechnics and professional accounting bodies) being strongly inspired to upgrade the curriculum of accounting education. In most developing countries, the mismatch between the supply and development of, and demand for, forensic accountants resonates with Carnes \& Gierlasinski's [24] concern: "Forensic Accounting Skills: Will Supply Finally Catch Up to Demand?".

This perceptible gap between the demand for and supply of skilled fraud examiners and forensic accountants underscores the need for this study. Precisely, Africa needs intense FEFA education. How does the supply side achieve this? There are two trajectories. The first and easier route is to integrate FEFA into extant undergraduate and postgraduate accounting programmes. The second approach which is more enduring in the supply of requisite FEFA skills is to mount the undergraduate programme (B.Sc.). The absence of NUC BMAS makes the first option more viable in the short run. On both counts, however, the views and insights from academics and practitioners are useful in integrating forensic accounting into accounting curriculum or redesigning forensic accounting courses in the Nigerian university system. 
Modern practice in curriculum development tends to build synergy with the labour market who is the primary user of university products. The interaction effects of the synergy identify strengths and deficiencies of graduates and proffer remedial measures to improve their competencies. Therefore, incorporating the views of practitioners in curriculum development is a useful corrective in revising the undergraduate benchmark minimum academic standards.

The broad objectives of this study are threefold: first, to establish the relevance (extent of needs and benefits) of forensic accounting education and practice in Nigeria; second, to ascertain the depth of FEFA through a webometric analysis of extant literature on fraud examination and forensic accounting in Nigeria; and third, to establish the required skills set for FEFA educators and practitioners in Nigeria, and by extension in Africa.

\section{Extant FEFA Research in Africa}

The interest here is to provide a synopsis of FEFA empirical research in Africa. Although the historicity of FEFA is not new, however, its popularity and growth is a recent trend. As noted above, the context of FEFA is founded on understanding the mind of the fraudster to identify why frauds and other related crimes are committed. As an emerging field of learning in Africa, the literature is just burgeoning. Table 2 is a webometric index of extant FEFA studies across Africa. The focus of most of the studies is on how forensic accounting can be used to mitigate fraud. With a few exceptions, notably Efiong [25] and Zango [26], most of the studies are on the use of forensic accounting for fraud-prevention and control. There has been little emphasis on how systematic FEFA education could be a useful tool in engendering accountability, transparency, and good governance in Nigeria and other African countries. 
Table 2: Webometric Indices of Fraud Examination \& Forensic Accounting Research in Nigeria \& Africa

\begin{tabular}{cl}
\hline Author \& Year of Publication & \multicolumn{1}{c}{ Title of Article } \\
\hline $\begin{array}{c}\text { Adefila, J. J., Kasum, A.S. \& } \\
\text { Olaniyi, T.A. (2005). }\end{array}$ & $\begin{array}{l}\text { The global endemic nature of } \\
\text { financial malpractices: An analytical } \\
\text { appraisal }\end{array}$ \\
Ajisebutu, A. (2006). & $\begin{array}{l}\text { Financial statement fraud: What } \\
\text { auditors should know }\end{array}$ \\
Appah, E. \& Appiah, K.Z. & $\begin{array}{l}\text { Fraud and development of sound } \\
\text { financial institutions in Nigeria }\end{array}$ \\
Dada, S. O., Owolabi, S. A., \& & $\begin{array}{l}\text { Forensic accounting: A panacea to } \\
\text { alleviation of fraudulent practices in } \\
\text { Okwu, A. T. (2013). }\end{array}$ \\
Nigeria \\
Fandago K. I. (1997). & $\begin{array}{l}\text { Fraud detection and control at local } \\
\text { government level }\end{array}$
\end{tabular}

Degboro, D., \& Olofinsola, J. (2007).

Efiong, E. J. (2012).

Ehioghiren, E.E and Atu, O.O.K. (2016).

Enofe, A. O., Okpako, P. O. \& Atube, E. N. (2013).

Izedomin, F.I \& Mgbame, C.O. (2011).

Jenfa, B. I. (2002).

Khan, S. A. (2005).

McIntyre J.L., van Graan, C., van Romburgh, J. \& van Zyl, A. (2014).

Modugu, K.P., \& Anyaduba J.O. (2013).

Mutua, C. (2014).

Njanike, K., Dube, T. \&

Mashanye, E. (2009).

Nurudeen, A. A. (2006).

Ogoun S. \& Obara L.C. (2013).

Okafor, B. (2004).

Okoye, E. I., \& Gbegi, D.O. (2013).

Okoye, E.I \& Gbegi, D.O., (2013).

Okunbor, J. A., \& Obaretin, 0. (2010).
Forensic accountants and the litigation support engagement.

Forensic accounting education: An exploration of level of awareness in developing economies - Nigeria as a case study.

Forensic accounting and fraud management: Evidence from Nigeria

The impact of forensic accounting on fraud detection

Curbing financial frauds in Nigeria: A case for forensic accounting

Internal control and fraud prevention: Accountant perspective

Corruption and professional practice: Issues and challenges

Contextualizing the South African forensic accountant

Forensic Accounting and financial fraud in Nigeria: An empirical approach

The effect of fraudulent practices on the growth of Insurance Companies in Kenya

The effectiveness of forensic auditing in detecting, investigating and preventing bank frauds

Role of the accountancy profession in tackling fraud

Curbing occupational and financial reporting fraud: An alternative paradigm

Strategic approach to reduction of employee, theft fraud and embezzlement.

An evaluation of forensic accountants to planning management fraud risk detection procedures

An evaluation of forensic accountants to planning management fraud risk detection procedures forensic accounting services in Nigerian organisations
Effectiveness of the application of
Journal

African Journal of Management, 1(1): $11-20$

The Nigerian Accountant, 39(2): 17

Nigerian Journal for Development Research; 1(1):49-56

International Journal of Business Management Economic Research, 4(5); 787-792

The Certified National Accountant, $7(4)$

Nigerian Accountant, 40(2): 49-52

International Journal of Business \& Management, 7(4): 26-34

Igbinedion University Journal of Accounting, 2: 245-308

European Journal of Business \& Management, 5(26): 61-72

African Journal of Humanities and Society, 12(1): 52-56

The Certified National Accountant, $10(4)$

The Nigerian Accountant, 38(4): 60

Journal of Forensic \& Investigative Accounting, 6(3): 98-153

International Journal of Business and Social Science, 4(7): 281-289

Journal of Management, 2(16): 301317

Journal of Sustainable Development in Africa, 10(4): 405-425

The Certified National Accountant, $10(4)$

International Journal of Business and Social Science, 4(9): 123-132

Nigerian Accountant, 37(4): 3-5

Global Journal of Management and Business Research, 13(1): 1-17

Global Journal of Management and Business Research, 13(1): 74-90

Journal of Management Sciences, 1(1): 171-184 
Owojori, A.A. \& Asaolu, T. O. (2009).

Oyejide, A. (2008).

Ribadu, N, (2005).

Sabo, B. (2001).

Williams, I. (2005).

Zango, A.G. (2012).
The role of forensic accounting in solving the vexed problem of corporate world

Corruption and development: A Nigerian perspective

Obstacle to effective prosecution of corrupt practice and financial crimes in Nigeria

Fraud prevention and control in Nigerian public service: The need for a dimensional approach

Corrupt practices: Implications for economic growth and development of Nigeria

The relevance of forensic accounting education in financial reporting
Journal of Scientific Research, 29(2):

Nigerian Accountant, 41(4): 28-42

A Paper presented at a 4-day Stakeholders Summit on Corrupt Practices Organized by House of Representatives Committee, Nigeria Journal of Business Administration, 1(2):118-133

The Nigerian Accountant, 38(4): 4450

Working Paper Series, Faculty of Management and Social Sciences, Umaru Musa Yar'adu University. https://ssrn.com/abstract=2193962

\section{Nature of FEFA Theory}

\section{THEORETICAL AND CONCEPTUAL FRAMEWORKS OF FEFA}

The important developments in the field of FEFA have not crystallized to a point where they can be condensed as coherent theoretical frameworks. However, two competing theoretical frameworks have dominated discussion in extant FEFA literature. These are the Fraud Triangle $^{2}$ and the Fraud Diamond ${ }^{3}$. To assess the efficacy of FEFA theories, it is apropos to examine the purpose of a theory. In other words, what is a theory supposed to accomplish? A theory has a trichotomy of purposes. First, a theory provides a coherent explanation or rationale for observed practice in the phenomenon or phenomena of interest, in this case, FEFA. Thus, the theory of FEFA should explain why fraud, corruption, financial crimes, and related vices occur, or why organizations use different ways to fight them.

The second objective of a theory is to predict and understand unobserved phenomena. Unobserved phenomena, according to Watts and Zimmerman [27] "are not necessarily future phenomena: they include phenomena that have occurred but on which systematic evidence has not been collected". The third objective of a theory is to challenge and extend existing knowledge of the phenomena. For the time being, the two FEFA theoretical frameworks - fraud triangle and fraud diamond - explicitly or implicitly underlie extant studies in fraud examination and forensic accounting within bounded rationality assumptions. They are the structures that hold or support our understanding of fraud and existing research studies. The foregoing encapsulates Hopwood, et al.'s [28] postulation that a fraud theory is "an organized set of suppositions related to the classic sleuth's questions of who, what, when, where, how, and why" of fraud. We contend that in all cases, these same classic detective's questions apply to forensic accounting theory. Thus, fraud and forensic accounting theory is coextensive. Accordingly, wherever and whenever fraud theory is used, it coextends to forensic accounting.

\footnotetext{
2The Fraud Triangle is a model developed by Dr. Donald Cressey, a criminologist whose research, in the 1940s, focused on the circumstances that led ordinary people to violate ethical standards and commit fraudulent acts. ${ }^{3}$ Wolfe \& Hermanson [32] propose the Fraud Diamond theory as an enhancement of the fraud triangle by introducing a fourth element, capability (to depict personal traits and abilities). Together with incentive, opportunity, and rationalization, capability plays a major role in whether fraud can actually occur. The complementarity of the four elements will help to improve both fraud prevention and detection.
} 


\section{Conceptual Framework}

Fraud examination and forensic accounting are evolving concepts and have become a fast developing specialist field of accounting in contemporary business. The first conceptual task is to understand why some people commit fraud. What drives or pushes them to commit fraud? For example, knowing that all mammals cannot survive without oxygen (breathing) easily explains why asphyxiation leads to death. Fraud theories provide some understanding of the trajectory of FEFA - who, what, when, where, how, and why fraud is committed. As a new field of learning, research is not only at its embryonic stage, especially in Africa, but also there is as yet no consensus on their dimensions. However, the diverse concepts can compactly be summarized as: (1) application of specialized knowledge and specific skills to stumble on the evidence of economic transactions [6] [28]; (2) the practice of rigorous data collection and analysis in the areas of litigation support consulting, expert witnessing, and fraud examination [29]; (3) the integration of accounting, auditing and investigative skills [30]; and (4) the action of identifying, recording, settling, extracting, sorting, reporting, and verifying past financial data or other accounting activities for settling current or prospective legal disputes or using such past financial data for projecting future financial data to settle legal disputes [31].

Fraud examination and forensic accounting are different but related. Fraud is a derivative of the conventional assumption that economic agents are guided by considerations of selfinterest to make allowance for strategic behaviour. The strategic behaviour is the self-interest seeking with intentional deception made for personal benefit or to harm another party. It has profound implications for formulating contractual relationships. Fraud examiners are antifraud professionals who are primarily concerned with resolving fraud allegations and assisting in fraud detection and prevention. Fraud examiners can be either accountants or nonaccountants and the examinations refer only to anti-fraud matters. The involvement relations encompass a variety of tasks that connect actual or potential civil or criminal litigation. On the other hand, forensic accountants are specifically trained accountants to investigate fraud, valuation, bankruptcy, and a range of other professional services in anticipation of litigation. Both forensic accounting and fraud examination are inter-disciplinary in nature: they embrace several other disciplines and professions than accounting. As shown in Figure 1, these include law, psychology, sociology, criminology, intelligence, information systems, computer forensics, and the greater part of forensic science fields [33]. One of the involvement challenges for nonaccountants is that most fraud and forensic engagements require at least some knowledge of accounting, finance, and economics because of the nature of the work (ibid.). Contextually therefore, forensic accounting or financial forensics is the nexus and application of the principles, skills and knowledge of the aforementioned disciplines in the analysis and investigation of financial data in a manner that is usable in a court of law in resolving cases of financial irregularities and various forms of occupational fraud. Put differently, it is the specialty practice field of accounting that investigates financial data and related engagements in matters involving actual or potential civil or criminal litigation. It is used in the detection and prevention of a broad range of occupational fraud and in any dispute that may be used as evidence in a law court.

\section{Developing the Frontiers of Knowledge and Skills in FEFA}

What is the idiosyncratic knowledge base that putatively distinguishes FEFA from their traditional accounting counterparts? There is little doubt that corporate organizations and the society at large have much faith in the ability of FEFA to checkmate the increasing incidence of fraud, corruption and financial crimes. There is equally no doubt that corporate organizations and regulatory agencies expect FEFA to be more proactive in preventing the growing rate of corruption, fraud, and financial crimes. Increasingly, society expects forensic accountants and fraud examiners to use their idiosyncratic skills and knowledge to repress these criminal activities, and therefore meet public opinion or expectation. This expectation is an implicit 
concession to bounded rationality which can be mitigated by dovetailed education and training. The education and training requires, in turn, a pedagogic process that is totally different from orthodox teaching and learning methods. An appropriate starting point is to identify the ontological and epistemological dimensions of FEFA. What are those critical skills and how can they be faithfully imparted?

\section{Characteristics and Skills of a Forensic Accountant}

Researchers, such as Cohen, Crain, \& Sanders [34], Harris and Brown [35], Mesmer [36] and Ramaswamy [37], have questioned what the idiosyncratic skills and technical abilities of forensic accountants are, and/or their experience levels [38]. Being an effective accountant does not necessarily make an effective forensic accountant [39]. With the rising rate of occupational fraud and financial crimes, particularly in developing countries with weak institutions and judiciary, the involvement relations of untrained and uncertificated forensic accountants and lawyers in FEFA are bound to suffocate, and could be detrimental to, the intricate task of investigation and prevention. Anecdotal evidence - through media hype, with no concrete evidence of prosecutorial success, of Nigeria's EFCC and ICPC, - is a pointer to the organizational implications of failure in task-specific education and training. The primary mandates of the two law enforcement agencies are interrelated but are respectively, fraud and financial crimes investigation and prevention, and corruption. Also, they are largely staffed by police officers from the Nigeria Police Force, the principal law enforcement agency in Nigeria.

Wells, Kranacher \& Riley [33] identify at least seven (7) knowledge and skills which the study of FEFA should encompass, namely: (i) Basic Accounting Concepts, (ii) Basic Auditing Concepts, (iii) Transaction Processing Cycles and Control Environment, (iv) Basic Finance and Economics, (v) Business Law Concepts, (vi) General Business Communications Skills and Business Ethics, and (vii) Basic Computer Skills. There is little, if any, to disagree with these knowledge frontiers. It is widely felt that education and training have an important, if not fully determinative, influence on the development of FEFA. The leading reason for this lies in the peculiar nature of FEFA education. Precisely, the education and training of forensic accountants is affected by an understanding of the elemental traits, characteristics and core skills appropriate to or necessary for the practice [39]. Davis, et al. [39], encapsulate the dynamics of these features in their sixteen (16) idiosyncratic propositions, in sequence: analytical, detail-oriented, ethical, responsive, insightful, inquisitive, intuitive, persistent, sceptical, evaluative, confident, and adaptive. In addition, s/he must have the drive to function under pressure, capacity to generate new ideas and scenarios, make people feel at ease and, above all, a team player. 


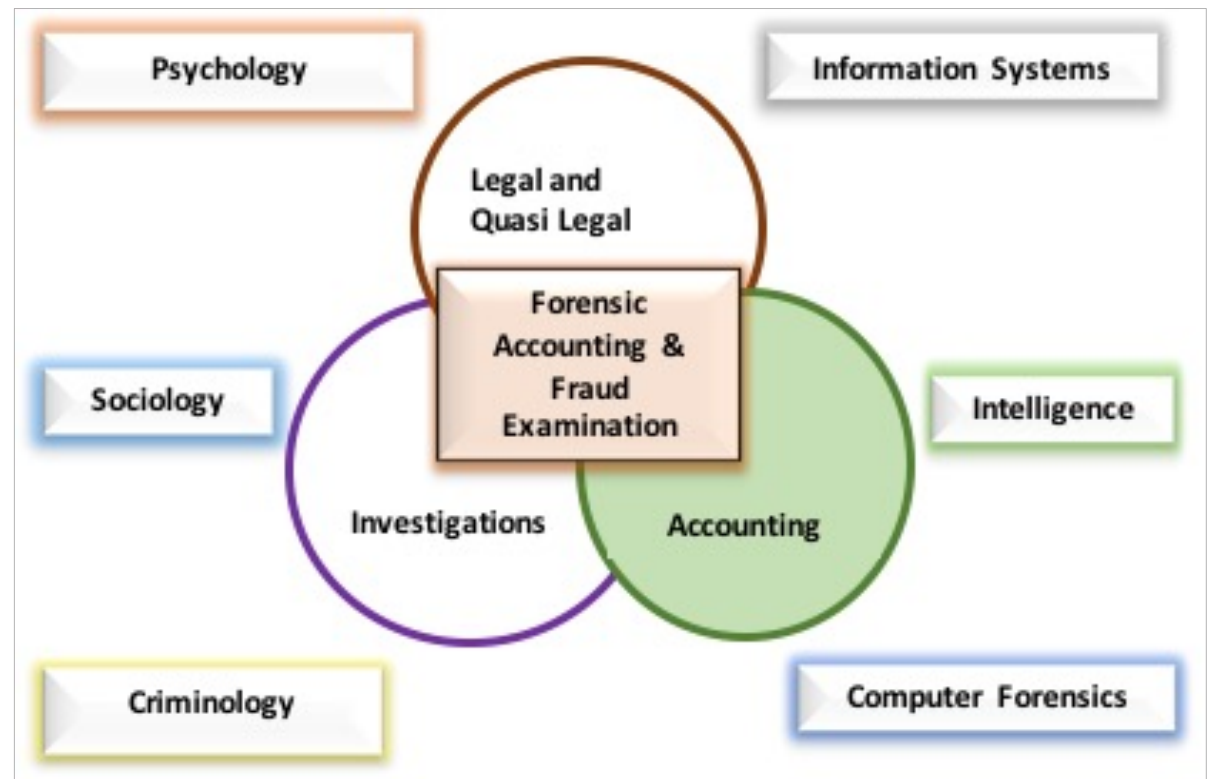

Figure 1: Requisite Skills of the African Forensic Accountant Source: Adapted with modifications from McIntyre, et al [40].

In addition to the foregoing, other functional indivisibilities that enhance forensic accounting skills include: effective oral and written communication skills; ability to simplify information or data; critical and strategic thinking, both like the fraudster and as the solution-provider; capacity to identify key issues; auditing and investigative skills, including investigative intuitiveness; ability to synthesize results of discovery and analysis; research skills with ability to comprehend the goals of a case, tell the story, see the big picture, organize an unstructured situation; and ability to solve both structured and unstructured problems. These skills constitute the pedagogic non-separabilities that define the professional competences and integrity of the forensic accountant. These are embedded in the education and training of forensic accountants and fraud examiners to equip them with the functional competences to (i) analyse and interpret financial statements; (ii) testify in law courts in accordance with general knowledge of rules of evidence in civil and criminal procedures; (iii) adapt to relevant professional standards; (iv) provide audit evidence and internal controls; (v) engage in interviews and investigations; (vi) undertake fraud detection and prevention, asset tracking, electronic trails and content, and text analyses; and (vii) provide mechanisms for conflict negotiation and dispute resolution. These enhanced core skills both determine the effectiveness of forensic accountants and fraud examiners and distinguish their education and training from traditional accounting disciplines.

The atmosphere of fraud examination and forensic accounting is summarized by the schematics in Figures 1 and 2. The main issues are the inter-disciplinary nature of education and practice of FEFA. In Figure 1, FEFA lies at the heart or intersection of professional practice that is embedded or anchored in accounting, legal, and investigation skills. In practice, certified forensic accountants and fraud examiners are trained to possess a triad of skills - technical competency, investigative proficiency, and critical thinking - to meet labour market expectations in employment respects and justify the perceived relevance and benefits of their specialized education. The cognitive domain of the forensic accountant and fraud examiner is distinctive and draws from a dichotomy of behavioural sciences (psychology, sociology, criminology) and digital forensics (information systems, intelligence, and computer forensics) (Figure 2). 


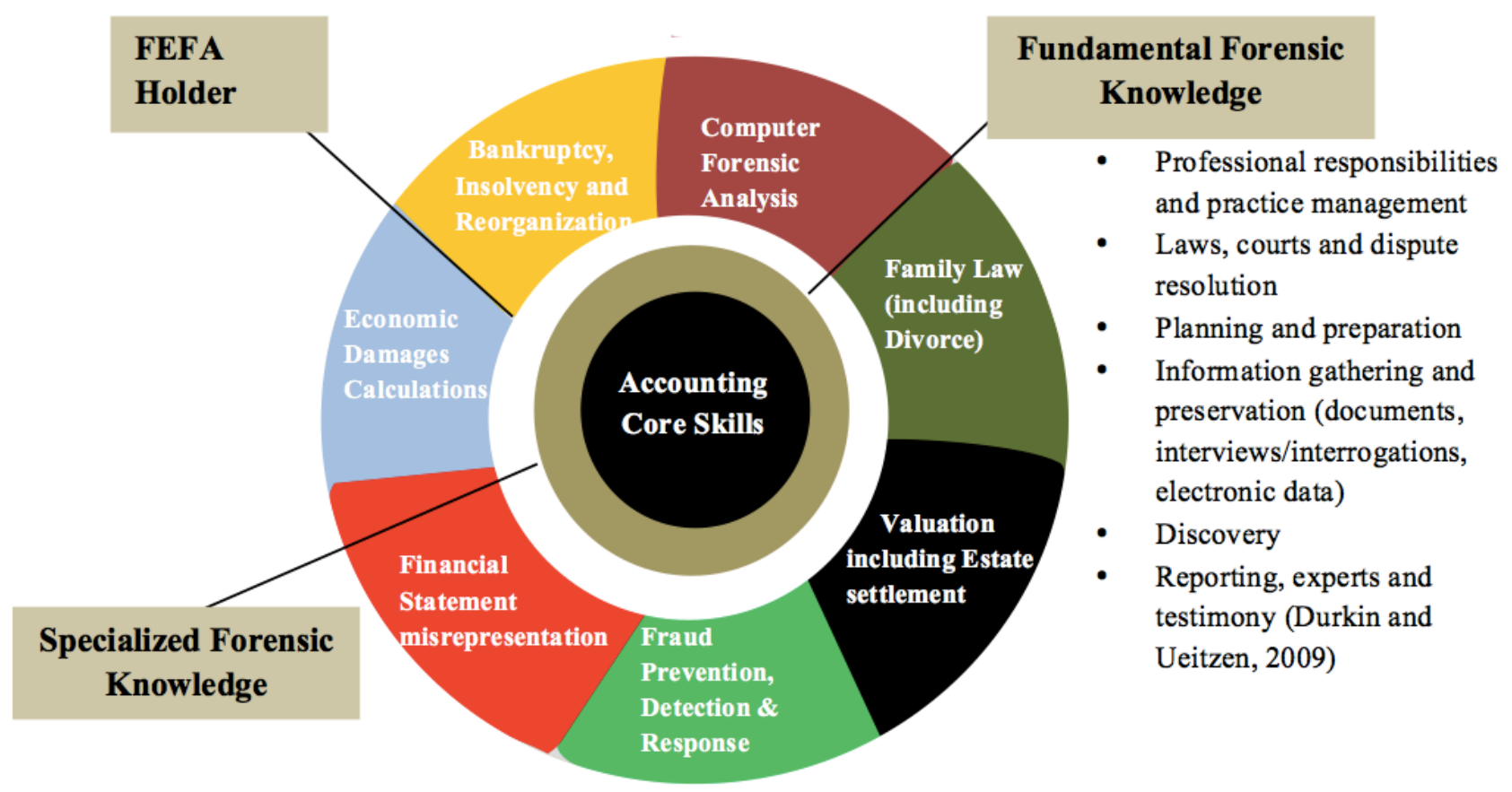

Figure 2: Focus of Fraud Examination and Forensic Accounting (FEFA)

Source: Adapted from Davies, et al [39].

The above skills-content guidance is expected to expand the choices of instructional tools and modes of delivery for the development of a successful career in forensic accounting and fraud examination. Furthermore, proper understanding of the ideal DNA of a well-trained and effective forensic accountant and fraud examiner is to provide a specialized landscape to professional associations and academic institutions to dovetail their training programmes or instructional modes to encompass all aspects of FEFA.

\section{Relevance and Benefits of FEFA Education}

Given the increased demand for FEFA education and practice, Crumbley, Rezaee and Elmore [29] present the perceived relevance and benefits of forensic accounting education and practice as follows: (1) Strengthening the credibility of financial reporting; (2) Promoting responsible corporate governance; (3) Increasing the demand for individuals possessing forensic accounting education and skills; (4) Preparing students to engage in fraud examination; (5) Making students more desirable in the marketplace; (6) Prepare students to engage in litigation support consulting; (7) Prepare students to engage in expert witnessing; and (8) Reduce the level of corporate fraud in an economy.

\section{CONCLUDING REMARKS AND RECOMMENDATION}

The argument of the preceding sections can be summarized as follows. First, a country's developmental trajectory is contoured by its political and economic leadership. Herbert [41] espouses that "if the roots of Africa's stunted development were series of poor policy decisions at both national and regional levels, the soil in which those roots were planted was an earth rotavated by corrupt leadership and bad governance". The economic consequences of corrupt leadership and bad governance are manifestly present in unbridled corruption, fraud, financial crimes and related vices. Relatedly, that corruption, fraud and financial crimes undermine democratic institutions, impede economic exchanges and development and destabilize governments and institutions, is scarcely novel. These vices weaken "the foundation of democratic institutions by distorting electoral processes, perverting the rule of law, and creating bureaucratic quagmires" [42]. These, in turn, create uncertainty which when joined 
with bounded rationality and opportunism give rise to exchange difficulties and socioeconomic and political backwardness.

Second, sequel to the foregoing, FEFA research matters because of its special relevance in exploring and documenting the bounded rationality dimensions (theoretical and empirical dynamics) of corruption, fraud, and financial crimes. Advantages of increasing knowledge base aside, by providing a distinct inventory of education and research, a better understanding of the idiosyncratic phenomenon of corruption in Nigeria and Africa can be synergized. The growing interest in the professional development of FEFA is evidentiary of the global concern of the prevalence of corruption and financial malpractices, especially in Sub-Saharan Africa (SSA). Third, studies looking at the features of corruption, fraud and financial crimes in developing countries are markedly different from the developed countries and from each other. This is precisely because the contexts in which organizational policies and strategies are formulated in both the public and private sectors in developing countries are fundamentally flawed by reason of bounded rationality (personal capabilities), fraud, corruption and associated vices and weak leadership and institutional structures. These endogenous factors combine with external influences to determine the limits of what the public and private sector organizations can successfully accomplish. Also, they compel a new research agenda to gravitate around (i) identifying and clarifying key characteristics of developing countries, especially those of SSA, that foster obscene corruption and abuse of office with impunity, gross indiscipline by the citizens, and obtrusive distortions of even well-crafted development agenda. In short, why do things (policies and programmes) that advance the course of humanity in developed countries not work in Africa?

Fourth, there is a muted agreement that FEFA education is relevant in Nigeria and, indeed in Africa. Efiong [25] and Zango [26] have made calls for the establishment of some form of forensic accounting education at tertiary level. Since this call was made, aside the affirmative response from the professional accounting associations, there is no other discernible evidence of positive supply response by purveyors of tertiary education in Nigeria. This further makes the case for more research attention in the subject area. Fifth, the regulatory apathy of tertiary education agencies with responsibility for programme accreditation points to the absence of a formal structure for FEFA education in Nigeria. For example, as earlier pointed out the NUC has no benchmark minimum academic standards (BMAS) for FEFA curriculum. Without the BMAS no university in Nigeria can mount an undergraduate programme in any discipline. This lacuna has gravely limited the growth of FEFA education in Nigeria. The professional bodies have not helped matters either, because of their limited knowledge and perfunctory approach to education and training.

Consequently, the study makes the following recommendations for a new development agenda. First, FEFA education cannot be conveniently subsumed under traditional accounting programmes. The leading difficulty where FEFA skills are idiosyncratic is that the education and training strategically require the incorporation of principles from a broad range of disciplines, as outlined above. The skill set and training is nearly impossible to capture under an accounting programme, thus making the current status of FEFA in Nigeria and Africa in general ineffectual. Second, the design and implementation of the development agenda can be facilitated by the joint involvement of tertiary education regulatory agencies and FEFA professionals. Arguendo, the introduction of degree programmes in FEFA will be a useful corrective to the current lacuna in the provision of systematic education in the discipline. It will also enhance the supply of urgently needed skilled manpower in the fight against corruption and economic and financial crimes. Third, although Nigerian affiliates of foreign professional bodies, such as the Association of Certified Fraud Examiners (ACFE) and the Institute of Certified Forensic Accountants (ICFA) have sprung up, the extent to which they are 
meaningfully engaged in anti-fraud investigations and litigation support cases is minimal. Studies have shown that education has a positive, albeit moderate, direct effects on corruption [43]. Above all, the tolerance of African culture to corruption can be ebbed and the beneficial effects of education on corruption enhanced with increased FDI flows and their interaction effects (ibid.).

That also explains in part the perennial lack of diligent prosecution of fraud and corruption cases by the EFCC and ICPC. There are corruption and financial crimes cases that have been unresolved, with no resolution in sight, for many years. It is instructive that some notable corruption cases whose prosecution started and stalled in the Nigerian courts have since been disposed of in the UK and the culprits have completed or are still serving their jail sentences. A major reason often cited by the Nigerian Judges for throwing out such cases is inchoate, hasty or want of diligent prosecution by law enforcement agents. Nigeria's anti-corruption agencies are quick to publicize corruption allegations in the media even before commencing diligent investigations.

Leading reasons for want of diligent investigation and prosecution are rooted in corruption and opportunistic proclivities of government officials, judges and lawyers, on the one hand and the deliberate exclusion of experts, like fraud examiners and forensic accountants on the other, in investigations and prosecutions. Furthermore, bypassing the fraud theory approach, especially in the case of complex fraud, not only makes the investigations infeasible, nebulous and uncoordinated, but also creates incomplete evidence for successful litigation. Besides, nonconformity to orthodox fraud-investigation process (that is, the fraud theory approach) is fraught with bounded rationality challenges which explain in part why many EFCC and ICPC cases are not painstakingly concluded.

In general, the above claims speak to the fundamental questions about the interaction effects of education and related research on Nigeria's (and Africa's) environment of corruption, culture and the development. The following are suggested actions: (i) measurable competence in FEFA should be made a criterion for practice in fraud and financial crimes prevention; (ii) prosecution and litigation support by FEFA experts to assist law enforcement agents with their work similar to the coroner or medical examiner; and (iii) institution of routine forensic audits and certification of organizations (both public and private) analogous to periodic financial audits of firms. Currently, forensic audit is undertaken only when there are suspicions of wrongdoing, that is, ex post. An ex ante approach should be adopted both to provide confidence in systems and to entrench a culture of transparency and accountability.

Since fraud has a unique imprint in Africa, a transactional interpretation of corrupt leadership and bad governance, in which the limitations of governments and markets in control respects are emphasized, reveals that the intolerable effects of antisocial consequences of corruption, fraud, occupational abuse and financial crimes are far greater in detail and ramifications than clearly understood and incorporated in mainstream financial and economic decisions. In this paper, we maintain that one can understand the powers and limits of fraud examination and forensic accounting only by examining each in relation to the other. Rather than focusing on corruption, fraud, financial crimes and related hazards, attention is on the implicit efficacy of forensic accounting and fraud examination. The policy ramifications mainly affect the bounded rationality properties of education, training and reorientation of societal values as a veritable tool in curbing the syndrome of corruption, fraud, and financial crimes in Nigeria and Africa in general. 


\section{References}

[1]. Coke, E., Institutes of the Laws of England, 1797. Part III.

[2]. Williamson, O.E., Markets and Hierarchies: Analysis and Antitrust Implications. 1975, New York: The Free Press (USA).

[3]. Herbert, W.E., Foreign Investment Strategies: A Comparative Study of the Use of the New Forms of Investment by UK \& Non-UK Multinationals, Research in International Business \& Finance, 1995. 12: p. 303-323.

[4]. Alchian, A.A. and Demsetz, H., Production, Information Costs, and Economic Organization. The American Economic Review, 1972.62: p. 777-795.

[5]. Stiglitz, J.E., An Agenda for the New Development Economics, 2001. Discussion Paper. The United Nations Research Institute for Social Development Meeting, 7-8 September: Cape Town, South Africa.

[6]. Joshi, M.S., Definition of Forensic Accounting, 2003. www.forensicaccounting.com \{retrieved March 1, 2017\}

[7]. Durkin, R. and Ueltzen, M., The Evolution of the CFF Credential. The Practicing CPA, 2009. 33(6), July/August.

[8]. Stone, D.N. and Miller, C.T., The State of and Prospects for, Forensic and Fraud Research that Matters. Journal of Forensic \& Investigative Accounting, 2012. 4(2): p. 35-76.

[9]. National Universities Commission, Benchmark Minimum Academic Standards for Undergraduate Programmes in Nigerian Universities, 2007, NUC: Abuja, Nigeria.

[10]. Association of Certified Fraud Examiners, Report to the Nation on Occupational Fraud and Abuse, 1996, ACFE: Austin, Texas, USA.

[11]. Association of Certified Fraud Examiners, Report to the Nation on Occupational Fraud and Abuse, 2014, ACFE: Austin, Texas, USA.

[12]. Association of Certified Fraud Examiners, Report to the Nation on Occupational Fraud and Abuse, 2015, ACFE: Austin, Texas, USA.

[13]. EY, Global Fraud Survey, 2015, EY: London, UK.

[14]. EY, Global Fraud Survey, 2016, EY: London, UK.

[15]. KPMG, Fraud Survey, 1994, Montvale: New Jersey, USA.

[16]. KPMG, Fraud Survey, 1998, Montvale: New Jersey, USA.

[17]. KPMG, Fraud Survey, 2003, Montvale: New Jersey, USA.

[18]. Melancon, B.C., A New Accounting Culture. Journal of Accountancy, 2002. October: p. 27-32.

[19]. Zimbelman, M.F., Albrecht, C.C., Albrecht, W.S. and Albrecht, C.O., Forensic Accounting. 4th Edition, 2012, Canada: South-Western Cengage Learning.

[20]. Seda, M. and Kramer, B., An Examination of the Availability and Composition of Forensic Accounting Education in the United States and Other Countries. Journal of Forensic \& Investigative Accounting, 2015. 6(1): p. 1-46.

[21]. Bundy, T.L., Ward, S.P. and Ward, D.R., Forensic Accounting: The Profession's New Growth Industry. Journal of Business, Industry and Economics, 2003. 3(1): p. 29-38.

[22]. Levine, S., Careers to Count On. U.S. News \& World Report, 2002. February 18: p. 46-48.

[23]. MacDonald, E., Accounting Sleuths Ferret Hidden Assets. Wall Street Journal, 1996. December 18: p. B1-B2.

[24]. Carnes, K.C. and Gierlasinski, N.J., Forensic Accounting Skills: Will Supply Finally Catch Up to Demand? Managerial Auditing Journal, 2001. 16(6): p. 378-382.

[25]. Efiong, E.J., Forensic Accounting Education: An Exploration of Level of Awareness in Developing Economies Nigeria as a Case Study. International Journal of Business and Management, 2012. 7(4): p. 26-34. 
[26]. Zango, A.G., The Relevance of Forensic Accounting Education in Financial Reporting. Umaru Musa Yar'adu University Faculty of Management and Social Sciences Working Paper Series, 2012.

[27]. Watts, R.L. and Zimmerman, J.L., Positive Accounting Theory. 1986, Englewood Cliffs, New Jersey: PrenticeHall (USA).

[28]. Hopwood, W.S., Leiner, J.J. and Young, G.R., Forensic Accounting and Fraud Examination. 2nd Edition, 2012, New York: McGraw-Hill Irwin (USA).

[29]. Crumbley, D.L., Rezaee, Z. and Elmore, R.C., Forensic Accounting Education: A Survey of Academicians and Practitioners. Journal of Forensic Accounting, 2004. 11(2): p. 181-202.

[30]. Zysman, A., Forensic Accounting Demystified. 2004, World Investigators Network Standard Practice for Investigative and Forensic Accounting Engagements, Canadian Institute of Chartered Accountant. 5(6).

[31]. Crumbley, D.L., Heitger, E. and Smith, G.S., Forensic and Investigative Accounting. 4th Edition, 2009, Chicago: CCH Incorporated (USA).

[32]. Wolfe, D. and Hermanson, D.R., The Fraud Diamond: Considering Four Elements of Fraud. The CPA Journal, 2004. 74(12): p. 38-42.

[33]. Wells, J., Kranacher, M. and Riley, R.A., Forensic Accounting and Fraud Examination. 2011, New York: John Wiley and Sons Inc. (USA).

[34]. Cohen, M., Crain, M.A. and Sanders, A., Skills Used in Litigation Services. Journal of Accountancy, 1996. 182(3): p. 101.

[35]. Harris, C.K. and Brown, A.M., The Qualities of a Forensic Accountant. Pennsylvania CPA Journal, 2000. $71:$ p. $2-3$.

[36]. Messmer, M., Exploring Options in Forensic Accounting. National Public Accountant, 2004. 5: p. 9-20.

[37]. Ramaswany, V., Corporate Governance and the Forensic Accountant. CPA Journal, 2005. 75(10): p. 63-68

[38]. Grippo, F.J. and Ibex, T., Introduction to Forensic Accounting. National Public Accountant, 2003. 4: p. 4-8.

[39]. Davis, C., Farrell, R. and Ogilby, S., Characteristics and Skills of the Forensic Accountant, 2009, AICPA Forensics and Valuation Services: New York, USA.

[40]. McIntyre, J.L., Van Graan, C., Van Romburgh, J.D. and Van Zyl, A., Contextualizing the South African Forensic Accountant. Journal of Forensic \& Investigative Accounting, 2014. Special International Issue, 6(3): p. 98153.

[41]. Herbert, W.E., Culture and Economic Security in Africa: Remodelling the Options, 2014, Policy Brief No. 3, Institute for African Culture and International Understanding: Lagos, Nigeria. July-Sept.: p. 1-14.

[42]. Independent Corrupt Practices Commission, ICPC Policy Statement, 2017. http://icpc.gov.ng/, \{retrieved March 20, 2017\}

[43]. Kwok, C.C.Y. and Tadesse, S., National Culture and Financial Systems. Journal of International Business Studies, 2006. 37: p. 227-247. 